Advances in Genetics-Endocrine Research

\title{
Genetic Overlap in Kallmann Syndrome, Combined Pituitary Hormone Deficiency, and Septo-Optic Dysplasia
}

\author{
Taneli Raivio, * Magdalena Avbelj,* Mark J. McCabe, Christopher J. Romero, \\ Andrew A. Dwyer, Johanna Tommiska, Gerasimos P. Sykiotis, Louise C. Gregory, \\ Daniel Diaczok, Vaitsa Tziaferi, Mariet W. Elting, Raja Padidela, Lacey Plummer, \\ Cecilia Martin, Bihua Feng, Chengkang Zhang, Qun-Yong Zhou, Huaibin Chen, \\ Moosa Mohammadi, Richard Quinton, Yisrael Sidis, Sally Radovick, \\ Mehul T. Dattani, and Nelly Pitteloud
}

\begin{abstract}
Children's Hospital (T.R., J.T.), Helsinki University Central Hospital, Institute of Biomedicine/Physiology, University of Helsinki, 00290 Helsinki, Finland; University Children's Hospital (M.A.), University Medical Centre Ljubljana, 1000 Ljubljana, Slovenia; Developmental Endocrinology Research Group Clinical and Molecular Genetics Unit (M.J.M., L.C.G., V.T., M.T.D.), University College London-Institute of Child Health, London EC1V 9EL, United Kingdom; Division of Pediatric Endocrinology (C.J.R., D.D., S.R.), The Johns Hopkins University School of Medicine, Baltimore, Maryland 21205; Endocrinology, Diabetes, and Metabolism Service of the Centre Hospitalier Universitaire Vaudois and University of Lausanne (A.A.D., Y.S., N.P.), 1011 Lausanne, Switzerland; Department of Internal Medicine, Division of Endocrinology, and Department of Pharmacology (G.P.S.), University of Patras Medical School, 26500 Patras, Greece; Department of Clinical Genetics and Human Genetics (M.W.E.), VU Medical Centre, 1081 HL Amsterdam, Netherlands; Department of Paediatric Endocrinology (R.P.), Royal Manchester Children's Hospital, Manchester M13 9WL, United Kingdom; Harvard Reproductive Endocrine Sciences Center and the Reproductive Endocrine Unit of the Department of Medicine (L.P., C.M., B.F.), Massachusetts General Hospital, Boston, Massachusetts 02114; Department of Pharmacology (C.Z., Q.-Y.Z.), University of California, Irvine, Irvine, California 92697; Department of Pharmacology, (H.C., M.M.), New York Uniersity School of Medicine, New York, New York; and Institute for Genetic Medicine (R.Q.), Newcastle University, and Department of Endocrinology, Newcastle upon Tyne Hospitals, Newcastle upon Tyne NE1 7RU, United Kingdom
\end{abstract}

Context: Kallmann syndrome (KS), combined pituitary hormone deficiency (CPHD), and septo-optic dysplasia (SOD) all result from development defects of the anterior midline in the human forebrain.

Objective: The objective of the study was to investigate whether KS, CPHD, and SOD have shared genetic origins.

Design and Participants: A total of 103 patients with either CPHD $(n=35)$ or SOD $(n=68)$ were investigated for mutations in genes implicated in the etiology of KS (FGFR1, FGF8, PROKR2, PROK2, and KAL1). Consequences of identified FGFR1, FGF8, and PROKR2 mutations were investigated in vitro.

Results: Three patients with SOD had heterozygous mutations in FGFR1; these were either shown to alter receptor signaling (p.S450F, p.P483S) or predicted to affect splicing (c.336C>T, p.T112T). One patient had a synonymous change in FGF8 (c.216G >A, p.T72T) that was shown to affect splicing and ligand signaling activity. Four patients with CPHD/SOD were found to harbor heterozygous rare loss-of-function variants in PROKR2 (p.R85G, p.R85H, p.R268C).

Conclusions: Mutations in FGFR1/FGF8/PROKR2 contributed to $7.8 \%$ of our patients with CPHD/ SOD. These data suggest a significant genetic overlap between conditions affecting the development of anterior midline in the human forebrain. (J Clin Endocrinol Metab 97: E694-E699, 2012)

ISSN Print 0021-972X ISSN Online 1945-7197

Printed in U.S.A.

Copyright (C) 2012 by The Endocrine Society

doi: 10.1210/jc.2011-2938 Received October 24, 2011. Accepted January 9, 2012.

First Published Online February 8, 2012

\footnotetext{
* T.R. and M.A. contributed equally to this work.

Abbreviations: CPHD, Combined pituitary hormone deficiency; FGF, fibroblast growth factor; FGFR, FGF receptor; GFP, green fluorescent staining; $I \mathrm{HH}$, idiopathic hypogonadotropic hypogonadism; KS, Kallmann syndrome; PROKR2, prokineticin receptor 2; SOD, septo-optic dysplasia; WT, wild type.
} 
In the vertebrate embryo, the preplacodal field arises at the edge of the neural plate adjacent to the neural crest, and its derivatives give rise to neuronal and nonneuronal head structures (1). Cells within the preplacodal field separate into individual placodes, of which the most anterior are the adenohypophyseal, lens, and olfactory placodes (1). The adenohypophyseal placode gives rise to the intermediate and anterior pituitary lobes (2). The olfactory placode gives rise to different cell types, including vomeronasal neurons, support cells, mucous-producing cells, and GnRH neurons (1). These developmental processes are orchestrated by multiple transcription factors and signaling molecules (2).

Mutations in the transcription factors $S O X 2, S O X 3$, HESX1, and OTX2 have been implicated in septo-optic dysplasia (SOD), a disorder characterized by pituitary hormone deficiencies, optic nerve hypoplasia, and midline defects including agenesis of the septum pellucidum and/or corpus callosum (3). Furthermore, mutations in transcription factors PROP1, POU1F1, LHX3, and LHX4 underlie combined pituitary hormone deficiency (CPHD) (4). However, such mutations only account for a small percentage of all CPHD/SOD cases.

A different set of genes have been implicated in Kallmann syndrome [KS; defined as idiopathic hypogonadotropic hypogonadism (IHH) and anosmia/hyposmia]. These genes, KAL1, PROK2, PROKR2, FGFR1, and $F G F 8$, play critical roles in the development of olfactory system and GnRH neuron ontogeny (5). KS manifests as absent or incomplete puberty, sexual immaturity, and infertility, and additional phenotypes include midline defects (5).

FGFR1 and FGF8 are expressed in Rathke's pouch and in the ventral diencephalon, respectively (6), and murine transcriptome data have identified members of the fibroblast growth factor (FGF)-8 signaling network during pituitary development (7). We therefore hypothesized that mutations in genes underlying KS could also underlie CPHD and/or SOD.

\section{Subjects and Methods}

\section{Patients and control subjects}

A total of 103 patients with either sporadic CPHD $(n=35)$ or sporadic SOD $(n=68)$ were included. Patients were recruited at four medical centers in the United States and the United Kingdom. Patients with SOD exhibited optic nerve hypoplasia, agenesis of the corpus callosum, and/or septum pellucidum on radiologic examination with or without pituitary hormone deficiencies (4). CPHD was diagnosed as a deficiency of at least two pituitary hormones. Unaffected control subjects $(\mathrm{n}=268)$ were also studied. The ethics committees of participating institutions approved the study, and written informed consent was obtained before participation from subjects/parents/guardians.

The description of DNA sequencing of KAL1, FGFR1, FGF8, $P R O K 2$, and PROKR 2 and the assessment of the functional consequences of FGF receptor (FGFR)-1, FGF8, and prokineticin receptor 2 (PROKR2) mutations have been previously reported. Detailed descriptions of these methods as well as a description of Prokr2 promoter reporter gene expression in the mouse pituitary are provided in the Supplemental Data, published on The Endocrine Society's Journals Online web site at http://jcem.endojournals.org.

\section{Results}

Among 103 patients with either CPHD $(\mathrm{n}=35)$ or SOD $(\mathrm{n}=68)$, four unrelated probands $(3.9 \%)$ harbor rare sequence variants in FGFR1 or FGF8, and four $(3.9 \%)$ have PROKR2 variants (Table 1). All mutations are heterozygous, and, in most cases, DNA from the parents was not available. The probands' phenotypic data are detailed in Table 1 and case descriptions are provided in the Supplemental Data. Notably, a number of probands exhibited a reproductive phenotype consistent with hypogonadotropic hypogonadism based on their neonatal presentation because they are yet prepubertal.

\section{FGFR1 and FGF8 mutations in patients with SOD}

Three FGFR1 heterozygous mutations were identified in SOD probands (Table 1). The FGFR1 variant c.1349C $>$ T, p.S450F maps to the intracellular domain of the receptor upstream of the tyrosine kinase domain and the amino acid (S450) is highly conserved across vertebrates (Supplemental Fig. 1A). The S450F mutant FGFR1 exhibits total protein and receptor cell surface expression levels (Fig. 1A and Supplemental Fig. 1B) similar to wild type (WT), yet downstream signaling is severely compromised (Fig. 1B). The FGFR1 variant c. $1447 \mathrm{C}>$ T p.P483S maps to a highly conserved residue in the tyrosine kinase domain. P483S also exhibits normal expression levels (Fig. 1A) but disrupted downstream signaling (Fig. 1B). Of note, the affected amino acid residue is also mutated in a patient with KS (c.1447C>A, p.P483T, Pitteloud, N., unpublished data). Subject 1 harbors a synonymous change (c.336C > T, p.T112T) mapping to the C-terminal end of immunoglobulin-like domain 1 (Supplemental Fig. 1A). This change was not observed in the 268 healthy controls, in the single-nucleotide polymorphism database or in the 1000 genomes data set. The Human Splicing Finder software (8) predicts that this variant generates a new exonic splicing enhancer binding site (TTACTTC) for the SRp40 splicing factor [score $79.46(0-100)$ ] and/or disrupts an overlapping putative exonic splicing enhancer octamer (CCTACTTC) (score 31.53). 
TABLE 1. Phenotypes of SOD and CPHD probands found to harbor gene mutations in either FGFR1, FGF8, or PROKR2

\begin{tabular}{|c|c|c|c|c|c|c|c|c|c|}
\hline Rare variant & $\begin{array}{l}\text { FGFR1 } \\
\text { T112T }\end{array}$ & $\begin{array}{l}\text { FGFR1 } \\
\text { S450F }\end{array}$ & $\begin{array}{r}\text { FGFR1 } \\
\text { P483S }\end{array}$ & $\begin{array}{r}\text { PROKR2 } \\
\text { R85G }\end{array}$ & $\begin{array}{l}\text { PROKR2 } \\
\text { R268C }\end{array}$ & $\begin{array}{l}\text { PROKR2 } \\
\text { R268C }\end{array}$ & $\begin{array}{l}\text { FGF8 } \\
\text { T72T }\end{array}$ & $\begin{array}{r}\text { PROKR2 } \\
\text { R85H }\end{array}$ & $\begin{array}{r}\text { KAL1 } \\
\text { H459Y }\end{array}$ \\
\hline Gender & Male & Male & Female & Female & Male & Male & Female & & Male \\
\hline $\begin{array}{l}\text { Abnormal pituitary MRI } \\
\text { Anterior pituitary } \\
\text { Posterior pituitary } \\
\text { Infundibular stalk }\end{array}$ & No & No & $\begin{array}{l}\text { Yes } \\
\text { Hypoplastic } \\
\text { Undescended }\end{array}$ & No & $\begin{array}{l}\text { Yes } \\
\text { Hypoplastic }\end{array}$ & $\begin{array}{l}\text { Yes } \\
\text { Ectopic } \\
\text { Agenesis }\end{array}$ & $\begin{array}{l}\text { Yes } \\
\text { Prominent }\end{array}$ & & N/A \\
\hline $\begin{array}{l}\text { Hormone deficiencies } \\
\text { GH } \\
\text { TSH } \\
\text { ACTH } \\
\text { LH/FSH } \\
\text { AVP }\end{array}$ & $\begin{array}{l}\text { Yes } \\
X\end{array}$ & $\begin{array}{l}x^{a} \\
x\end{array}$ & $\begin{array}{l}\text { Yes } \\
X \\
X \\
X \\
X^{a}\end{array}$ & $\begin{array}{l}\text { Yes } \\
X \\
X \\
X^{a}\end{array}$ & Yes & $\begin{array}{l}\text { Yes } \\
X \\
X \\
X \\
X^{a}\end{array}$ & $\begin{array}{l}\text { Yes } \\
X \\
X \\
X\end{array}$ & & $\begin{array}{l}\text { Yes } \\
X \\
X \\
X \\
X \\
X^{a}\end{array}$ \\
\hline $\begin{array}{l}\text { Ocular defects } \\
\text { Optic nerves } \\
\text { Optic disc } \\
\text { Other }\end{array}$ & $\begin{array}{l}\text { Yes } \\
\text { Abnormal eyes }\end{array}$ & No & $\begin{array}{l}\text { Yes } \\
\text { Micropthalmia } \\
\text { coloboma }\end{array}$ & $\begin{array}{l}\text { Yes } \\
\text { Agenesis (L) }\end{array}$ & $\begin{array}{l}\text { Yes } \\
\text { Hypoplasia }\end{array}$ & $\begin{array}{l}\text { Yes } \\
\text { Hypoplasia } \\
\text { Hypoplasia }\end{array}$ & No & & No \\
\hline $\begin{array}{l}\text { Reproductive phenotypes } \\
\text { Cyrptorchidism } \\
\text { Microphallus } \\
\text { Delayed puberty }\end{array}$ & N/A & N/A & $\mathrm{N} / \mathrm{A}$ & $\mathrm{N} / \mathrm{A}$ & $\begin{array}{l}\text { Yes } \\
X\end{array}$ & $\begin{array}{l}\text { Yes } \\
X \\
X\end{array}$ & $\begin{array}{l}\text { Yes } \\
\mathrm{X}\end{array}$ & & $\begin{array}{l}\text { Yes } \\
x\end{array}$ \\
\hline Other phenotypes & Seizures & $\begin{array}{l}\text { ASD and VSD, } \\
\text { brachydactyly, } \\
\text { brachycephaly, } \\
\text { preauricular } \\
\text { skin tags }\end{array}$ & None & $\begin{array}{l}\text { Club foot, syrinx } \\
\text { spinal cord }\end{array}$ & $\begin{array}{l}\text { Microcephaly, } \\
\text { epilepsy }\end{array}$ & None & None & & None \\
\hline
\end{tabular}

MRI, Magnetic resonance imaging; AVP, arginine vasopressin; ASD, atrial septal defect; VSD, ventricular septal defect.

a Hypogonadotropic hypogonadism is based on neonatal diagnosis (phenotype: cryptorchidism/micorphallus or low serum gonadotropins or LHRH stimulation test).

A synonymous change in FGF8 (c.216G >A p.T72T) was identified in a CPHD proband. This variant (Supplemental Table 1) is predicted by the Human Splicing Finder program (8) to compromise an exonic splicing enhancer site for the serine/arginine-rich splicing factor SF2/ASF (9). We generated a minigene expression construct, which includes the entire FGF8 gene (exons 1a to 3) except for $2.4 \mathrm{~kb}$ of intron $1 \mathrm{~d}$ sequence (Supplemental Fig. 2), to measure relative expression levels of the four FGF8 isoforms in transfected cells using quantitative RT-PCR. Consistent with the software prediction, the e and $\mathrm{f}$ isoform transcripts (which incorporate an alternatively spliced exon, 1c) expressed from the mutant construct were significantly elevated compared with WT (Fig. 1C). We further assessed the biological significance of the minigene-induced alterations in gene expression and found that the mutant construct displayed significantly higher activity in a luciferase transcription reporter assay compared with WT (Fig. 1D).

\section{PROKR2 and KAL1 mutations in patients with SOD or CPHD}

Three different $P R O K R 2$ mutations were found in four patients with SOD or CPHD. One Caucasian and one African SOD proband both harbor the identical heterozygous PROKR2 variant (c.802C >T, p.R268C) (Table 1 and Supplemental Fig. 3A), previously reported in association with both normosmic IHH and KS $(10,11)$ and shown to be loss of function in vitro (11). The other PROKR2 variant (c.253C $>$ G, p.R85G) found in a SOD proband affects an amino acid conserved across vertebrates (Supplemental Fig. 3A) and is predicted to be loss of function (Supplemental Table 1). Western analysis indicates reduced total protein expression suggesting a defect in protein folding and stability (Fig. 1E). Accordingly, cell surface expression is significantly reduced (Fig. 1F) accompanied by a severe decrease in signaling via both calcium (Fig. 1G) and MAPK (Supplemental Fig. 3B) (log 
A

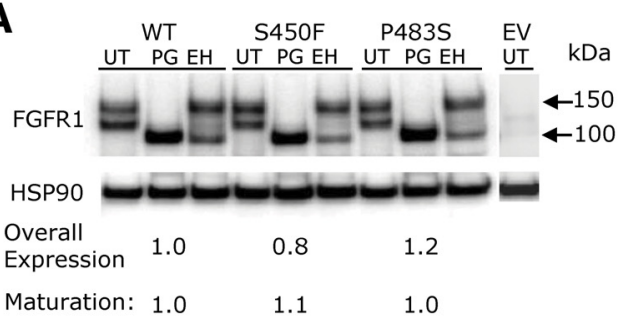

Maturation: $1.0=1.1-1.0$

C

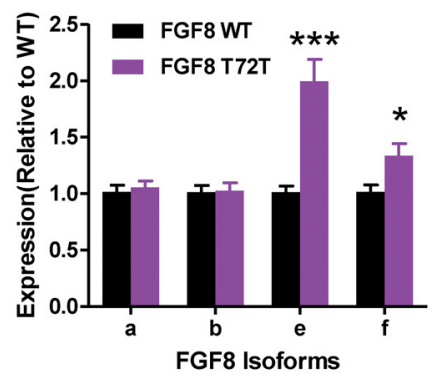

E

$\mathbf{F}$
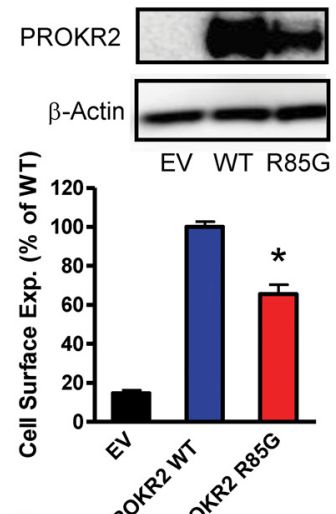

G

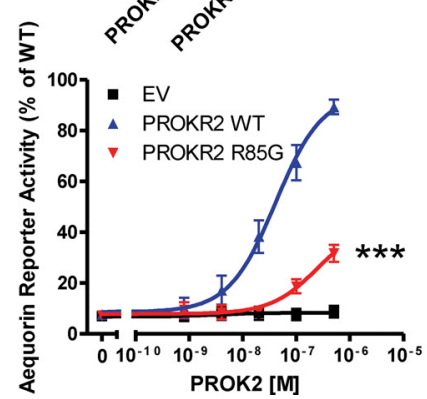

FIG. 1. A, Western blotting analysis showing similar overall expression and maturation levels of mutant FGFR1 compared with WT. FGFR1 was detected using an anti-myc antibody and the blot was reprobed with heat-shock protein 90 to demonstrate equal loading. UT, Untreated; PG, PNGase F treated; EH, endoglycosidase H treated; HSP90, heat-shock protein 90. B, Luciferase reporter assay using the osteocalcin FGF response elements reporter showing decreased signaling activity by FGFR1 S450F and FGFR1 P483S. ***, $P<0.001$ at maximal dose. C, Quantitative PCR showing that expression of both the FGF8e and FGF8f isoforms is significantly increased compared with WT. $\left.{ }^{*} * *, P<0.001 ; *{ }^{*} P<0.05\right)$. D, Representative experiment of a transcriptional reporter (AP1-luciferase) assay of FGF8 WT and T72T mutant minigene showing increased signaling activity by the mutant ligand compared with WT. $*, P<0.05$ at maximal dose. E, Western analysis showing that overall expression of the PROKR2 mutant (R85G) is reduced compared with WT. F, Expression of the PROKR2 R85G mutant at the cell surface is significantly reduced compared with WT. *, $P<0.05$ in a radiolabeled antibody binding assay. G, The PROKR2 R85G mutant receptor is loss of function in the aequorin reporter assay. ${ }^{* *}, P<0.001 . \mathrm{H}$, Prokr2 is expressed in the adult mouse pituitary. Immunofluorescent staining for GFP in the pituitary of Prokr2-GFP transgenic mice shows immunoreactivity in all pituitary structures and is most pronounced in the pars nervosa. AVP, Arginine vasopressin.
$\mathrm{EC}_{50} \mathrm{WT}-6.944 \pm 0.155, \mathrm{R} 85 \mathrm{G}$ $-6.319 \pm 0.267, P<0.05)$ cascades.

A CPHD proband, born with a microphallus (suggesting neonatal GnRH deficiency), harbors a rare variant in KAL1 (c.1375C > T), inherited from his mother, and a mutation in PROKR2 (c.254G $>$ A, p.R85H) inherited from his father. The $\mathrm{R} 85 \mathrm{H}$ mutation has been reported in KS patients (12) and is loss of function in vitro (13). Transgenic mice expressing green fluorescent staining (GFP) under control of the Prok2 promoter shows GFP immunoreactivity throughout the pituitary structures, and especially in the pars nervosa (Fig. 1H), further supporting a role for PROK2 signaling in the pituitary.

\section{Discussion}

We describe eight prepubertal patients with CPHD/SOD carrying a heterozygous mutation in FGFR1, FGF8, or PROKR2, associated with altered function. Thus, mutations in genes generally associated with $\mathrm{IHH} / \mathrm{KS}$ may also be associated with CPHD/SOD, demonstrating a genetic overlap between these syndromes. Patients with KS often display midline defects such as cleft lip and/or palate and corpus callosum anomalies, and FGF8 mutations were recently found to be associated with recessive holoprosencephaly, craniofacial defects, and hypothalamo-pituitary dysfunction (6). Additionally, as early as in 1954, de Morsier described a syndrome of dysplasie olfacto-génitale, which included agenesis of the olfactory bulbs, corpus callosum, and the anterior commissure as well as infantile genitalia (14). Although the hypogonadotropic hypogonadism observed in both CPHD and SOD is thought to be of pituitary origin, the verification of hypothalamic GnRH deficiency in these patients is difficult, if not impossible, because of the concomitant presence of a pituitary defect. 
As with the FGFR1 mutations in IHH/KS patients, the mutations identified in SOD probands are also loss of function. In contrast, the FGF8 mutation in the CPHD proband shows enhanced downstream receptor signaling. The rare synonymous change in FGF8 leads to differential expression of FGF8 isoforms and enhanced FGFR1 signaling in vitro. Thus far, gain-of-function FGFR1 mutations have been reported only in osteoglophonic dysplasia and Pfeiffer syndrome. Of note, $40 \%$ of patients with Apert syndrome (caused by activating FGFR2 mutations) have partial or complete absence of the septum pellucidum and $23 \%$ have corpus callosum defects (15), phenotypes also observed in SOD. Thus, it remains unclear whether CPHD is caused by increased (and not decreased) FGF signaling or, more broadly, by any significant perturbation of FGF signaling.

There are some precedents of IHH/KS sharing the same genetic basis with another developmental disorder. $\mathrm{Mu}$ tations in CHD7 occur in CHARGE syndrome (coloboma, heart defect, choanal atresia, retardation, genital hypoplasia, ear anomalies) and KS patients (16). Similarly, a frameshift mutation in SOX2 associated with anophthalmia/microphthalmia was also found in an IHH patient (17), suggesting that SOD and IHH share a genetic basis. Furthermore, deletion of Otx2, a locus for SOD, targeted to $\mathrm{GnRH}$ neurons results in hypogonadotropic hypogonadism in mice (18).

We also evaluated the PROK2/PROKR2 pathway in patients with CPHD/SOD, identifying three loss-of-function mutations in PROKR2 in four unrelated CPHD/SOD probands. The PROKR2 R268C variant has been described in heterozygous state in IHH/KS patients, healthy first-degree relatives of KS probands, and in one of 250 healthy controls $(10,12)$. We therefore propose that these mutations do not cause major midline defects per se, but may act as modifier genes, or contribute to the phenotype through digenic inheritance, as previously demonstrated in IHH/KS $(19,20)$. Thus, further studies are needed to elucidate the role of PROKR2 signaling in pituitary and midline development. In conclusion, this report identified substantial genetic overlap between syndromes affecting the anterior midline and associated with the primitive placode.

\section{Acknowledgments}

We are grateful to the patients and families for participating in the study and to Dr. Catherine M. Hall (deceased) for important contributions. This study was registered at www.ClinicalTrials. gov (NCT00494169).
Address all correspondence and requests for reprints to: Nelly Pitteloud, M.D., Centre Hospitalier Universitaire Vaudois, Endocrine, Diabetes, and Metabolism Service, BH 19-701, Rue du Bugon 46, 1011, Lausanne, Switzerland. E-mail: nelly.pitteloud @chuv.ch mailto.

This work was supported by Eunice Kennedy Shriver National Institute of Child Health and Human Development/ National Institutes of Health Grants R01HD056264, HD15788, and U54HD41859 as part of the Specialized Cooperative Centers Program in Reproduction and Infertility Research, the Swiss National Foundation, the Academy of Finland, and the U.K. Endocrine Research Fund. Fellowship support was provided by the Slovene National Research Agency Grant P30343 (to M.A.), the Pew Latin American Fellows Program in the Biomedical Sciences (to C.M.), and the Eunice Kennedy Shriver National Institute of Child Health and Human Development/ National Institutes of Health Grant T32 HD007396 (to B.F.).

Disclosure Summary: The authors have nothing to declare.

\section{References}

1. Schlosser G 2006 Induction and specification of cranial placodes. Dev Biol 294:303-351

2. Kelberman D, Rizzoti K, Lovell-Badge R, Robinson IC, Dattani MT 2009 Genetic regulation of pituitary gland development in human and mouse. Endocr Rev 30:790-829

3. McCabe MJ, Alatzoglou KS, Dattani MT 2011 Septo-optic dysplasia and other midline defects: the role of transcription factors: HESX1 and beyond. Best Pract Res Clin Endocrinol Metab 25:115124

4. Pfäffle R, Klammt J 2011 Pituitary transcription factors in the aetiology of combined pituitary hormone deficiency. Best Pract Res Clin Endocrinol Metab 25:43-60

5. Brioude F, Bouligand J, Trabado S, Francou B, Salenave S, Kamenicky P, Brailly-Tabard S, Chanson P, Guiochon-Mantel A, Young J 2010 Non-syndromic congenital hypogonadotropic hypogonadism: clinical presentation and genotype-phenotype relationships. Eur J Endocrinol 162:835-851

6. McCabe MJ, Gaston-Massuet C, Tziaferi V, Gregory LC, Alatzoglou KS, Signore M, Puelles E, Gerrelli D, Farooqi IS, Raza J, Walker J, Kavanaugh SI, Tsai PS, Pitteloud N, Martinez-Barbera JP, Dattani MT 2011 Novel FGF8 mutations associated with recessive holoprosencephaly, craniofacial defects, and hypothalamo-pituitary dysfunction. J Clin Endocrinol Metab 96:E1709-E1718

7. Brinkmeier ML, Davis SW, Carninci P, MacDonald JW, Kawai J, Ghosh D, Hayashizaki Y, Lyons RH, Camper SA 2009 Discovery of transcriptional regulators and signaling pathways in the developing pituitary gland by bioinformatic and genomic approaches. Genomics 93:449-460

8. Desmet FO, Hamroun D, Lalande M, Collod-Béroud G, Claustres M, Béroud C 2009 Human Splicing Finder: an online bioinformatics tool to predict splicing signals. Nucleic Acids Res 37:e67

9. Smith PJ, Zhang C, Wang J, Chew SL, Zhang MQ, Krainer AR 2006 An increased specificity score matrix for the prediction of SF2/ASFspecific exonic splicing enhancers. Hum Mol Genet 15:2490-2508

10. Abreu AP, Trarbach EB, de Castro M, Frade Costa EM, Versiani B, Matias Baptista MT, Garmes HM, Mendonca BB, Latronico AC 2008 Loss-of-function mutations in the genes encoding prokineticin-2 or prokineticin receptor- 2 cause autosomal recessive Kallmann syndrome. J Clin Endocrinol Metab 93:4113-4118

11. Monnier C, Dodé C, Fabre L, Teixeira L, Labesse G, Pin JP, Hardelin JP, Rondard P 2009 PROKR2 missense mutations associated with Kallmann syndrome impair receptor signalling activity. Hum Mol Genet 18:75-81 
12. Dodé C, Teixeira L, Levilliers J, Fouveaut C, Bouchard P, Kottler ML, Lespinasse J, Lienhardt-Roussie A, Mathieu M, Moerman A, Morgan G, Murat A, Toublanc JE, Wolczynski S, Delpech M, Petit C, Young J, Hardelin JP 2006 Kallmann syndrome: mutations in the genes encoding prokineticin-2 and prokineticin receptor-2. PLoS Genet 2:e175

13. Caronia LM, Martin C, Welt CK, Sykiotis GP, Quinton R, Thambundit A, Avbelj M, Dhruvakumar S, Plummer L, Hughes VA, Seminara SB, Boepple PA, Sidis Y, Crowley Jr WF, Martin KA, Hall JE, Pitteloud N2011 A genetic basis for functional hypothalamic amenorrhea. N Engl J Med 364:215-225

14. DeMorsier G 1954 Études sur les dysraphies cranio-encéphaliques. I. Agenesie des lobes olfactifs (téléncéphaloschizis lateral) et des commisures calleuse et anterieure (téléncéphaloschizis median). La dysplasie olfacto-génitale. Schweizer Archiv von Neurologie und Psychiatrie (Archives Swisses de Neurologie et Psychiatrie) 74:309361

15. Quintero-Rivera F, Robson CD, Reiss RE, Levine D, Benson CB, Mulliken JB, Kimonis VE 2006 Intracranial anomalies detected by imaging studies in 30 patients with Apert syndrome. Am J Med Genet A 140:1337-1338

16. Kim HG, Kurth I, Lan F, Meliciani I, Wenzel W, Eom SH, Kang GB, Rosenberger G, Tekin M, Ozata M, Bick DP, Sherins RJ, Walker SL,
Shi Y, Gusella JF, Layman LC 2008 Mutations in CHD7, encoding a chromatin-remodeling protein, cause idiopathic hypogonadotropic hypogonadism and Kallmann syndrome. Am J Hum Genet 83:511-519

17. Stark Z, Storen R, Bennetts B, Savarirayan R, Jamieson RV 2011 Isolated hypogonadotropic hypogonadism with SOX2 mutation and anophthalmia/microphthalmia in offspring. Eur J Hum Genet 19:753-756

18. Diaczok D, DiVall S, Matsuo I, Wondisford FE, Wolfe AM, Radovick S 2011 Deletion of Otx2 in GnRH neurons results in a mouse model of hypogonadotropic hypogonadism. Mol Endocrinol 25: 833-846

19. Pitteloud N, Quinton R, Pearce S, Raivio T, Acierno J, Dwyer A, Plummer L, Hughes V, Seminara S, Cheng YZ, Li WP, Maccoll G, Eliseenkova AV, Olsen SK, Ibrahimi OA, Hayes FJ, Boepple P, Hall JE, Bouloux P, Mohammadi M, Crowley W 2007 Digenic mutations account for variable phenotypes in idiopathic hypogonadotropic hypogonadism. J Clin Invest 117:457-463

20. Sykiotis GP, Plummer L, Hughes VA, Au M, Durrani S, NayakYoung S, Dwyer AA, Quinton R, Hall JE, Gusella JF, Seminara SB, Crowley Jr WF, Pitteloud N 2010 Oligogenic basis of isolated gonadotropin-releasing hormone deficiency. Proc Natl Acad Sci USA 107:15140-15144

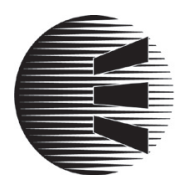

\section{Get ready for the 2012 ABIM board exam in endocrinology, diabetes, and metabolism with Endocrine Board Review, 3rd edition.}

